Zeszyty Naukowe Szkoły Głównej Gospodarstwa Wiejskiego w Warszawie Problemy Rolnictwa Światowego tom 17 (XXXII), zeszyt 1, 2017: 43-52

DOI: 10.22630/PRS.2017.17.1.4

Maria Grzybek $^{1}$, Wiesław Szopiński

Uniwersytet Rzeszowski

\title{
Zachowania konsumentów na rynku produktów regionalnych i tradycyjnych
}

\section{Consumer Behaviour of Buyers on the Market of Regional and Traditional Products}

\begin{abstract}
Synopsis. W opracowaniu dokonano oceny zachowań konsumentów na rynku produktów regionalnych i tradycyjnych w woj. podkarpackim. W analizie empirycznych wyników badania dotyczących 600 konsumentów z woj. podkarpackiego wykazano kategorię nabywanych produktów regionalnych i tradycyjnych, miejsca realizacji zakupów, częstotliwość i motywy zaopatrywania się w tego rodzaju artykuły spożywcze oraz zjawisko etnocentryzmu występujące wśród badanych. $\mathrm{Na}$ podstawie badania należy stwierdzić że w woj. podkarpackim ma miejsce dynamiczny rozwój rynku omawianych produktów w kontekście sprzyjających warunków naturalnych, dziedzictwa kulinarnego oraz przy dużym zaangażowaniu władz samorządowych. Konsumenci wykorzystują wszystkie możliwe źródła zaopatrzenia. Preferują zwłaszcza wysoką jakość, bezpieczeństwo spożycia, smak, świeżość i lokalne pochodzenie. Wykazali się także etnocentryzmem, gdyż regionalne i lokalne pochodzenie produktów ma dla nich istotne znaczenie.
\end{abstract}

Słowa kluczowe: konsumenci, produkty regionalne i lokalne.

\begin{abstract}
The study assesses the behaviour of consumers on the market of regional and traditional products in Podkarpackie province. In the analysis of the empirical results of the study on 600 consumers from Podkarpackie province there were indicated categories of purchased regional and traditional products, shopping venues, frequency and motives of buying this type of food and the phenomenon of ethnocentrism occurring among respondents. Based on the study it should be stated that in Podkarpackie province there is a dynamic development in the market of the above-mentioned products in the context of favourable natural conditions, culinary heritage and strong involvement of local authorities. Consumers use all possible sources of supply. They especially appreciate high quality, consumption safety, taste, freshness and local origin. They also showed ethnocentrism, as local and regional origin of the products is essential for them.
\end{abstract}

Key words: consumers, local and regional products.

\section{Wstęp}

W 2016 roku minęło ponad 30 lat od funkcjonowania rynku produktów regionalnych i tradycyjnych w 16 krajach Unii Europejskiej, a 12 lat występowania tego rynku w Polsce. Wiodącą pozycją w rozwoju regionalnych specjałów zajmują: Włochy, Francja, Hiszpania, Portugalia i Grecja. Mimo relatywnie krótkiego okresu istnienia tego segment rynku w kraju od samego początku, jak podkreślają Jasiński i Rzytki (2007) ma miejsce dynamiczny

${ }^{1}$ dr hab. prof. UR, Katedra Marketingu i Przedsiębiorczości Uniwersytet Rzeszowski, ul. M. Ćwiklińskiej 2, 35-601 Rzeszów, e-mail: marketing@ur.edu.pl

${ }^{2}$ dr, Katedra Marketingu i Przedsiębiorczości Uniwersytet Rzeszowski, ul. M. Ćwiklińskiej 2, 35601 Rzeszów, e-mail: wszopin@ur.edu.pl 
jego rozwój. Zjawisko to należy uznać za bardzo pozytywne biorąc pod uwagę fakt, że ten rodzaj produktów stanowi w każdym kraju Unii wyjątkowe dobro dziedzictwa narodowego i bogactwa kulturowego.

Kondarciuk (2015) zauważa, że w kraju występują trzy definicje produktów regionalnych i tradycyjnych. Za pierwszoplanową uznaje definicję obowiązującą we wspólnym systemie UE dotyczącym oznaczeń produktów tego rodzaj (Chronionej Nazwie Pochodzenia, Chronionym Oznaczeniu Geograficznym, Gwarantowanej Tradycyjnej Specjalności). Druga jest podawana w krajowym systemie „Jakość Tradycja” (www.produktyregionalne.pl/produkty...). Trzecią natomiast stosuje się dla produktów aplikujących na Listę produktów tradycyjnych, prowadzoną przez Ministerstwo Rolnictwa i Rozwoju Wsi (www.minrol.gov.pl/Jakosc...). Oprócz aspektu terytorialnego, czasowego i kulturowego co między innymi podkreśla Jordana (2000), w każdej definicji najmocniejszy aspekt położony jest na zasadniczą cechę tych wyrobów jaką jest ich wysoka jakość. Cecha ta ma szczególne znaczenie, gdyż jak podkreślają Kowalska, Olszańska i Urban (2016), jakość konsumowanej żywności wpływa nie tylko na stan zdrowia człowieka, ale także na jego zdolność do zawodowej i społecznej aktywności.

Do zmiany zachowań konsumentów na rynku artykułów spożywczych przyczynia się rozwój rynku produktów regionalnych i tradycyjnych w kraju, wzrost wiedzy konsumentów na temat tego segmentu artykułów spożywczych, jak również świadomość wartościowych cech tych oryginalnych produktów (Borowska, 2015), a także większa dbałość Polaków o zdrowy sposób odżywiania się (Woźniak, 2003) oraz przekształcanie dotychczas występującego model konsumpcji w konsumpcję bardziej zrównoważoną, zapewniającą konsumentom lepszą jakość życia z poszanowaniem środowiska naturalnego i z myślą o zabezpieczeniu konsumpcji dla przyszłych pokoleń (Czubała, 2012).

Województwo podkarpackie należy do przodujących regionów w kraju oferujących ten rodzaj artykułów spożywczych. Świadczy o tym liczba produktów wpisanych na ministerialną Listę Produktów Tradycyjnych, która w latach 2006-2016 plasowała to województwo na trzech pierwszych pozycjach (www.minrol.gov.pl/Jakosc...). Występuja zatem wyraźne symptomy po stronie podaży, sprzyjające rozwojowi tego segmentu rynku, w tej części Polski.

Głównym celem opracowania było przedstawienie uwarunkowań rozwoju rynku produktów regionalnych i tradycyjnych $\mathrm{w}$ woj. podkarpackim, jak również wyników badania empirycznego dotyczącego zachowań rynkowych konsumentów zaopatrujących się $\mathrm{w}$ tę kategorię produktów.

\section{Dane i metody}

W opracowaniu wykorzystano pierwotne źródła informacji. Zebrano je dzięki użyciu narzędzia badawczego, jakim był samodzielnie przygotowany kwestionariusz ankiety. Anonimowe badania ankietowe przeprowadzono w 2016 roku metodą wywiadu bezpośredniego ${ }^{3}$. Objęto nimi łącznie 600 konsumentów. Badaną próbę wyodrębniono na zasadach doboru celowego, przeprowadzając wywiad wśród konsumentów zaopatrujących się $\mathrm{w}$ regionalne i lokalne artykuły konsumpcyjne, a także doboru kwotowego

3 Badanie przeprowadzili studenci Wydziału Ekonomii Uniwersytetu Rzeszowskiego, realizujący prace dyplomowe pod kierunkiem autorów artykułu. 
odzwierciedlającego płeć, wiek i miejsce zamieszkania. Uwzględniono także miesięczny dochód przypadający na jednego członka rodziny. Według przyjętych kryteriów kobiety stanowiły $52 \%$, mężczyźni natomiast $48 \%$. Wiek 18-24 lat dotyczył $20 \%$ badanych, a $24-$ 39 lat - 33\%. Największy odsetek konsumentów pochodził z przedziału 40-59 lat i wynosił $36 \%$. Konsumenci wiekowo najstarsi reprezentowali $21 \%$ badanej zbiorowości. Udział mieszkańców miast wyniósł $46 \%$, natomiast obszarów wiejskich $54 \%$. Biorąc pod uwage kryterium dochodu przypadającego na członka rodziny należy zauważyć że w $16 \%$ dotyczył on konsumentów o dochodach do 600 zł, w $29 \%$ o poziomie dochodów 601-1000 zł, w $30 \%$ o dochodach $1001-1500 \mathrm{zl}$, a w $25 \%$ dochody przekraczały poziom $1500 \mathrm{zt}$. Interpretując dane empiryczne wykorzystano metodę indukcyjno-dedukcyjna. Wyniki badania można wykorzystać do porównania $\mathrm{z}$ danymi pochodzącymi z innych województw w kraju, gdyż mają regionalny charakter.

\section{Uwarunkowania i rozwój rynku produktów regionalnych i tradycyjnych na Podkarpaciu}

Województwo podkarpackie zajmuje 5,7\% powierzchni i zamieszkuje w nim 5,5\% ludności kraju (www.polskawliczbach.pl). Zaliczane jest do najczystszych ekologicznie regionów Polski, ze względu na fakt, że aż 44,9\% powierzchni województwa charakteryzuje się szczególnymi walorami przyrodniczymi, które podlegają ochronie prawnej. W kraju natomiast analogiczny wskaźnik średni jest o 12,4 pkt. proc. niższy i wynosi $32,5 \%$. Nieskażone zatem ekologiczne obszary rolnicze w tym regionie posiadaja odpowiednie warunki do wytwarzania wysokiej jakości i bezpiecznej dla zdrowia żywności. Ponadto bogata przeszłość historyczna Podkarpacia sprawiła, że ta część kraju stanowi dziedzictwo kultur i tradycji różnych narodowości takich jak: polskiej, austriackiej, żydowskiej, niemieckiej, węgierskiej, ukraińskiej i ormiańskiej. Wyróżnikiem regionu jest także fakt, że oprócz kuchni dworsko-kresowej i kuchni chłopskiej występowała także pasterska kuchnia wołoska. Dzięki sprzyjającemu nieskażonemu środowisku naturalnemu, różnym narodowościom i bogatemu dziedzictwu kulinarnemu występują bardzo korzystne warunki do rozwoju produktów regionalnych i tradycyjnych, charakteryzujących się dużą atrakcyjnością dla konsumentów.

Sprzyjające warunki do produkcji regionalnych i tradycyjnych specjałów są efektywnie wykorzystywane przez producentów z regionu. Świadczy o tym ciagły wzrost produktów na ministerialnej Liście produktów tradycyjnych. W 2006 roku na 130 artykułów w kraju wpisanych na Listę 21 pochodziło z Podkarpacia, co uplasowało to województwo na drugim miejscu w Polsce. W 2010 roku na 742 wyroby krajowe 85 było z Podkarpacia, dzięki czemu województwo znalazło się na trzeciej pozycji. Pierwsze miejsce natomiast z liczbą 207 zajęło w 2016 roku na 1543 wszystkich polskich produktów zamieszczonych na Liście. Ze względu na kategorię wyrobów pochodzących z woj. podkarpackiego w 2016 rok na Liście występowało: 71 produktów mięsnych, 46 wyrobów cukierniczych i piekarniczych, 45 gotowych dań i potraw, 16 produktów mlecznych, 13 napojów, 9 warzyw i owoców, 2 oleje i thuszcze oraz 2 produkty rybołówstwa (www.minrol.gov.pl/Jakosc ...). Na uwagę zasługuje także fakt, że w Unii Europejskiej zarejestrowane zostały dwa produkty pochodzące z Podkarpacia. Jest to „Podkarpacki miód spadziowy", który 7.08.2010 roku został zarejestrowany jako Chroniona Nazwa Pochodzenia oraz „Fasola wrzawska” zarejestrowana 11.01.2012 rok, także jako Chroniona 
Nazwa Pochodzenia (www.podkarpackiesmaki.pl ...). Ponadto certyfikaty „Jakość Tradycja" zostało przyznane 21 produktom pochodzącym od 9 producentów z woj. podkarpackiego takim jak np.: Zakładowi Mięsnemu „Smak Górno”, Gospodarstwu Rybackiemu w Starzawie, Gminnej Spółdzielni „Samopomoc Chłopska” Rymanów, Spółdzielni Cukierniczej „Roksana”, w Strzyżowie, Przedsiębiorstwu Przemysłu Mięsnego „Taurus” w Pilźnie, Okręgowej Spółdzielni Mleczarskiej w Jasienicy Rosielnej i Makaronom Polskim S.A. (www.produktyregionalne.pl/edc ...).

Rozwój rynku produktów regionalnych i tradycyjnych bardzo aktywnie jest wspierany przez samorząd województwa, który organizuje, bądź współorganizuje różnego rodzaju wydarzenia promujące wysokiej jakości żywność regionalną i tradycyjną. W 2012 roku wydał „Leksykon Podkarpackich Smaków”, popularyzując i wspierając lokalnie działających producentów żywności regionalnej i tradycyjnej. Od 2014 roku w siedzibie Urzędu Marszałkowskiego organizowany jest Podkarpacki Piknik Produktów Regionalnych i Tradycyjnych. Cyklicznie od 2007 roku w Rzeszowie odbywają się Międzynarodowe Targi Produktów i Żywności Wysokiej Jakości „Ekogala”, które należą do największych w Polsce i Europie Wschodniej. Promowaniem żywności regionalnej i tradycyjnej zajmuje się także Oddział Terenowy Agencji Rynku Rolnego w Rzeszowie oraz Stowarzyszenie na Rzecz Rozwoju i Promocji Podkarpacia „Pro Carpathia”. W 2013 roku powstał Szlak Kulinarny Podkarpackie Smaki, który zrzesza obiekty gastronomiczne w województwie takie jak: karczmy, restauracje i zajazdy. Każda z tych placówek posiada w swoim menu przynajmniej trzy potrawy regionalne bądź tradycyjne. Szlak zachęca do zwiedzania i poznawania województwa poprzez bogatą tradycję kulinarną. Aktualnie liczy 5 obiektów i jest najdłuższym szlakiem kulinarnym w Polsce (www.podkarpackiesmaki.pl/pl/kulinaria-podkarpackie/aktualnosci ...).

\section{Zachowania konsumentów z Podkarpacia na rynku produktów regionalnych i tradycyjnych}

W omawianym województwie konsumenci mają możliwość nabywania produktów regionalnych $\mathrm{i}$ tradycyjnych $\mathrm{w}$ kilku miejscach ich sprzedaży. Na rysunku 1 zaprezentowano odsetek wypowiedzi ankietowych dotyczących rodzajów źródeł zaopatrzenia $w$ regionalne i tradycyjne specjały.

Ze struktury wypowiedzi wynika, że ponad jedną trzecią stanowili konsumenci zaopatrujący się $\mathrm{w}$ spożywczych placówkach detalicznych zarówno małych jak i wielkopowierzchniowych, oferujący ten rodzaj produktów. Dominująca część wypowiedzi $(83,3 \%)$ wystąpiła wśród osób najstarszych oraz mieszkańców miast $(82,8 \%)$. Również z badania Żakowskiej-Biemans (2012) wynika, że sklepy spożywcze oraz supermarkety są najczęstszym miejscem zakupu tego rodzaju artykułów spożywczych. Ponad jedna czwarta badanych nabywała je w firmowych sklepach producentów tej kategorii żywności. W tym przypadku jedną trzecią stanowili mężczyźni i konsumenci w wieku 40 do 59 lat. Dla co siódmego ankietowanego źródłem zaopatrzenia były placówki detaliczne zdrowej żywności. W nich zaopatrywały się przede wszystkim co czwarta kobieta, co piaty ankietowany w wieku $25-39$ lat i $28 \%$ z dochodem na członka rodziny powyżej 1500 zł. Również dla co siódmego konsumenta miejscem zakupu regionalnych i tradycyjnych specjałów były organizowane w gminach targi i wystawy tych produktów. Z 
tej okazji omawiane wyroby nabywali zwłaszcza mężczyźni (29\%), jedna trzecia osób w wieku 18-24 lat, mieszkańcy wsi (71,4\%).

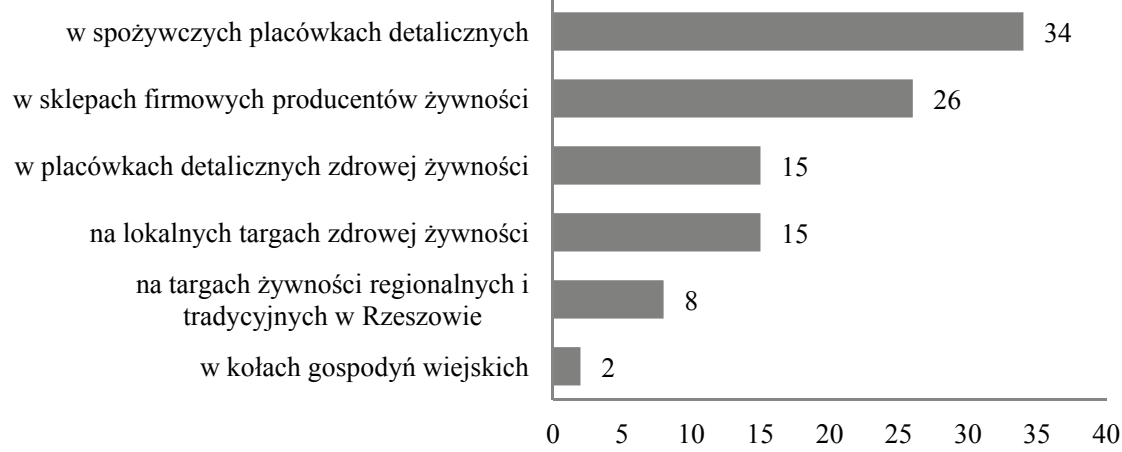

Rys. 1. Miejsce zakupu omawianych produktów, badanych konsumentów (\% wskazań)

Fig. 1. Place of purchase of products being discussed according to surveyed consumers (\% of responses)

Źródło: obliczenia własne na podstawie przeprowadzonego badania ankietowego.

Co dwunasty wypowiadający się kupował tą żywność na targach tych specjałów organizowanych każdego roku $\mathrm{w}$ Rzeszowie. Należą do nich takie imprezy jak: zapoczątkowane w 2005 roku Rzemieślnicze Święto Chleba organizowane przez Izbę Rzemieślniczą i Cech Rzemiosł Różnych oraz Podkarpackie Święto Miodu. Odbywające się od 2007 roku Międzynarodowe Targi Produktów i Żywności Wysokiej Jakości „Ekogala”, których organizatorem jest Związek Stowarzyszeń Podkarpacka Izba Rolnictwa Ekologicznego wraz z Urzędem Marszałkowskim. Urząd Marszałkowski, Urząd Gminy Sokołów Małopolski oraz Zakłady Mięsne „Smak Górno” od 2007 roku są organizatorami corocznych Targów Żywności Tradycyjnej „Festiwal Podkarpackich Smaków”, odbywających się w miejscowości Górno. Jako źródło zaopatrzenia podkarpaccy konsumenci podali także koła gospodyń wiejskich, jednak odsetek tych wypowiedzi był nieznaczny.

Uwzględniając wprowadzony przez Ministerstwo Rolnictwa i Rozwoju Wsi podział produktów regionalnych i tradycyjnych na kilka kategorii, w zależności od rodzajów artykułów spożywczych (www.minrol.gov.pl/Jakosc ...) w badaniu zastosowano to kryterium. Na rysunku 2 zaprezentowano odsetek wypowiedzi na temat najczęściej nabywanych produktów, zaliczanych do poszczególnych kategorii.

$\mathrm{Na}$ podstawie zaprezentowanych danych należy zauważyć że największy udział w strukturze kupowanych produktów zajęły artykuły mięsne, nabywane przede wszystkim przez kobiety $(70,8 \%)$, osoby w wieku najmłodszym $(75 \%)$, mieszkańców miast $(55,8 \%)$, o dochodach na członka rodziny w przedziale $1001-1500$ zł (57,5\%). Drugą pozycję zajęły produkty mleczne, preferowane zwłaszcza przez mężczyzn (39,6\%), konsumentów w wieku $18-24$ lat (43,8\%), ze środowiska miejskiego (55,2\%), o dochodach powyżej $1500 \mathrm{zł}$ (48\%). Trzecie miejsce według struktury wypowiedzi przypadło wyrobom piekarniczym i cukierniczym , którymi były zainteresowane w największym stopniu kobiety $(52,1 \%)$, konsumenci w wieku 25-39 lat (36,7\%), mieszkańcy miast (39,5\%), nabywcy z przedziału o dochodach 1001- 1500 zł na osobę w rodzinie (62,5\%). Na kolejnej pozycji znalazły się owoce i warzywa, które cieszyły się największym popytem występującym wśród mężczyzn 
$(52,8 \%)$, w grupie wiekowej 25-39 lat (36,7\%), wśród mieszkańców miast $(46,4 \%)$, o dochodach powyżej $1500 \mathrm{zł}(45 \%)$.

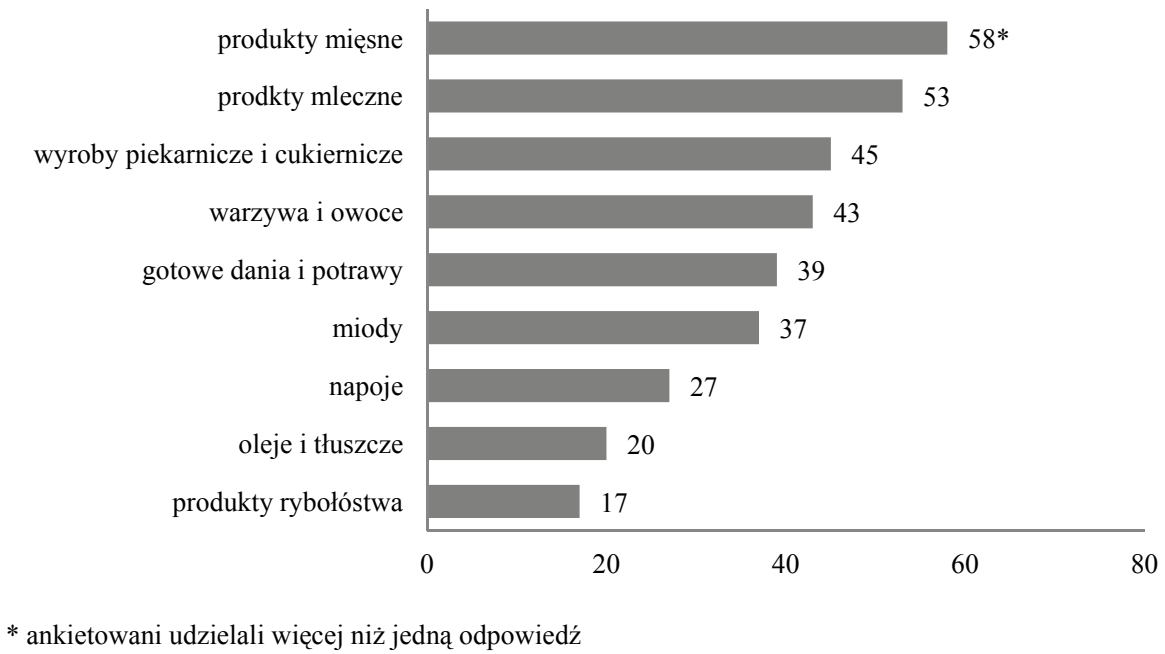

Rys. 2. Kategorie omawianych produktów najczęściej nabywanych przez badanych konsumentów (\% wskazań)

Fig. 2. Categories of products most frequently purchased by surveyed consumers (\% of responses)

Źródło: obliczenia własne na podstawie przeprowadzonego badania ankietowego.

Nabywcami gotowych dań i potraw byli w większości mężczyźni (51,9\%), konsumenci z grupy wiekowej 40-59 lat $(46,7 \%)$, mieszkańcy wsi $(55,2 \%)$. W miód zaopatrywały się przeważnie kobiety $(41,7 \%)$, jedna trzecia konsumentów w wieku 25-39 lat i wiekowo najstarszych, pochodzących z miast (41,4\%), z grupy dochodowej 10011500zł (42,5\%). Wyniki badania wskazują, że znacznie mniej zainteresowani byli konsumenci produktami regionalnymi i tradycyjnymi należącymi do trzech pozostałych kategorii tych artykułów, a zwłaszcza produktów rybołówstwa.

O zachowaniach rynkowych konsumentów i zainteresowaniu spożywaniem regionalnych i tradycyjnych produktów świadczy także częstotliwość nabywania tych specjałów. Zagadnienie przedstawia rysunek 3.

Jak widać na rysunku w grupie badanych konsumentów tylko co siódmy z nich dokonywał zakupów omawianych produktów kilka razy w tygodniu. Dotyczyło to spośród ankietowanych co piątej kobiety, osób w wieku $40-59$ lat $(31,6 \%)$, ponad $27 \%$ mieszkańców miast i reprezentujących dochody powyżej 1500 zł na osobę w rodzinie $(27,6 \%)$. Raz w tygodniu w produkty regionalne i tradycyjne zaopatrywał się co czwarty $\mathrm{z}$ badanej zbiorowości. W tym przypadku także większy udział od mężczyzn stanowiły kobiety (30\%), nabywcy $\mathrm{z}$ grupy wiekowej 25-39 lat (42,9\%), prawie jedna czwarta mieszkańców miast i konsumenci o dochodach $1001-1500$ zł na osobę w rodzinie $(35 \%)$. Natomiast co najmniej raz $\mathrm{w}$ miesiącu realizował zakupy specjałów regionalnych i lokalnych co piąty konsument $\mathrm{z}$ badanej populacji. W tym przypadku przewagę o 7,8 pkt. proc. nad kobietami mieli mężczyźni. $Z$ tą częstotliwością realizowała zakupy jedna czwarta osób w wieku 18-24 lat oraz prawie jedna piąta mieszkańców wsi. Podobne 
zjawisko ukształtowało się $\mathrm{w}$ przypadku dokonywanych zakupów rzadziej niż raz w miesiącu.

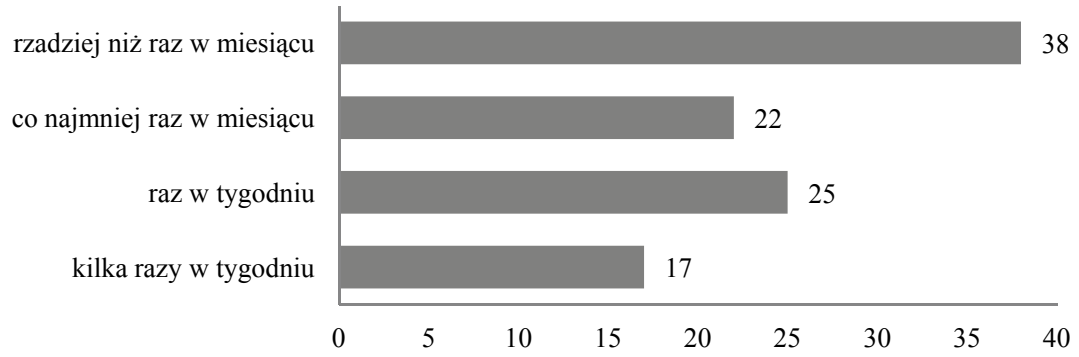

Rys. 3. Częstotliwość zakupu omawianych produktów przez badanych konsumentów (\% wskazań)

Fig. 3. Frequency of purchase of products by surveyed consumers ( $\%$ of responses)

Źródło: obliczenia własne na podstawie przeprowadzonego badania ankietowego.

Mężczyźni stanowili $36 \%$, osoby z grupy najmłodszej $45 \%$, prawie jedna czwarta mieszkańców wsi i aż trzy czwarte konsumentów reprezentujących dochody najniższe na członka rodziny.

Pod względem podejmowanych decyzji o nabyciu, konsumpcji i zaspokajaniu potrzeb pokarmowych, artykuły spożywcze stanowią szczególna grupe towarów. Dlatego tak istotne są cechy, którymi kierowali się badani nabywcy produktów regionalnych i tradycyjnych w woj. podkarpackim. Wyniki przedstawia rysunek 4.

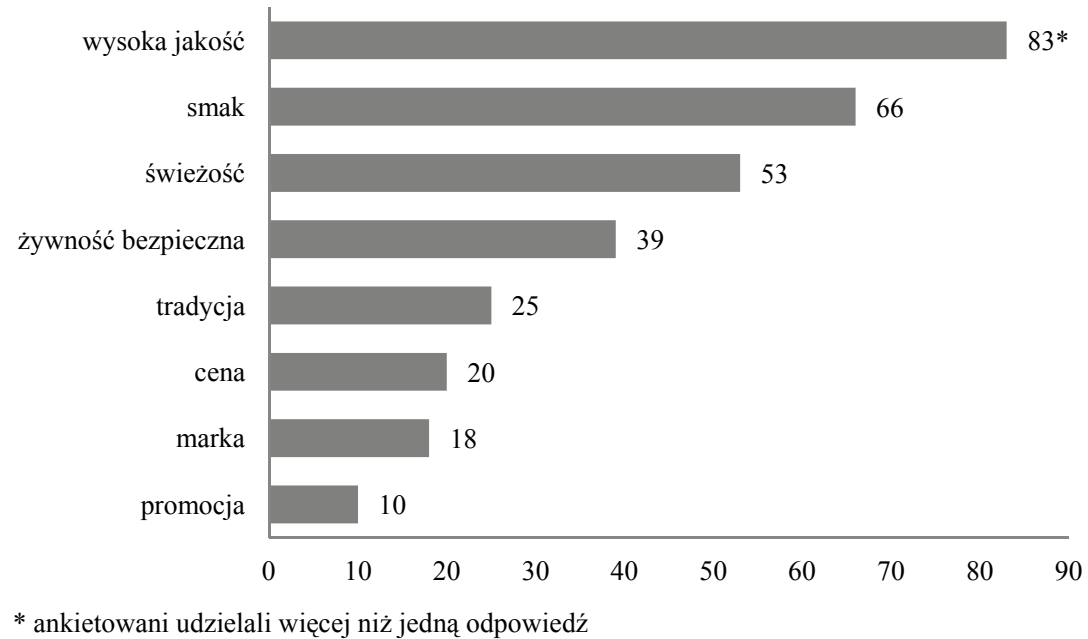

Rys. 4. Cechy omawianych produktów brane pod uwagę przy ich zakupie przez badanych konsumentów (\% wskazań)

Fig. 4. Characteristics of products taken into consideration when shopping by surveyed consumers (\% of responses)

Źródło: obliczenia własne na podstawie przeprowadzonego badania ankietowego. 
Udział wypowiedzi wskazuje, że wśród ogółu badanych dominowały opinie o wysokiej jakości produktów regionalnych i tradycyjnych, która stała się zasadniczym czynnikiem decydującym o ich nabywaniu (83\%). Dla większości badanych ważną rolę odgrywały także właściwości sensoryczne tych specjałów takie jak smak i świeżość. Są to cechy na które przy spożyciu zwraca uwagę każdy człowiek. Znaczny odsetek wypowiadających się (39\%) podkreślił przywiązywanie dużej wagi do żywności bezpiecznej dla zdrowia, jako czynnika decydującego o popycie. Dla co czwartego konsumenta ważna była tradycja reprezentowana przez te unikalne wyroby. Wytwarzanie produktów tradycyjnymi metodami, dzięki przekazywaniu wiedzy z pokolenia na pokolenie, jest także doceniane wśród konsumentów z innych krajów UE (Stolzenbach, Bredie i Byrne, 2013). Na znacznie niższych pozycjach, w strukturze wypowiedzi znalazły się elementy marketingowe takie jak cena, marka i promocja. Na uwagę zasługuje fakt, że o ile na przełomie XX i XXI wieku polscy konsumenci zwracali uwagę w pierwszej kolejności na cenę co wynikało z badań Kowrygo i współautorek (1997) to od 2006 roku wysoka jakość produktów, zwłaszcza regionalnych, staje się priorytetowym czynnikiem popytotwórczym w Wielkopolsce (Jąder, 2006), w kraju (Kuśmierczyk i SzepieniecPuchalska, 2008), na Podkarpaciu (Grzybek, 2009). Również czynniki sensoryczne konsumenci uznają za bardzo ważne w momencie podejmowania decyzji o zakupie żywności, co podkreśla Jeznach (2012). Natomiast Grzybowska-Brzezińska (2012) zauważa, że wśród coraz bardziej wymagających Polaków, nurty w konsumpcji żywności wskazują na przywiązywanie większej wagi do bezpiecznej diety, a w konsekwencji do bezpiecznej żywności, w związku z czym cecha ta nabiera coraz większego znaczenia przy realizacji zakupów.

W literaturze przedmiotu (Radziszewska, 2015), zwraca się uwagę na etnocentryczne zachowania konsumentów, dla których istotne znaczenie ma pochodzenie produktów, zwłaszcza spożywczych. Dlatego też zwrócono w badaniu uwagę na to zagadnienie, a otrzymane wyniki prezentuje rysunek 5 .

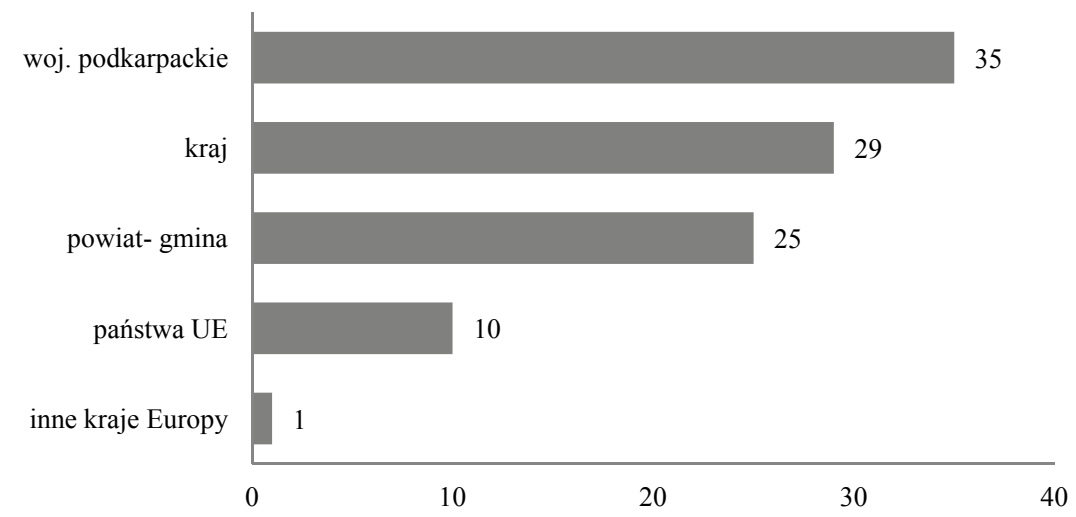

Rys. 5. Preferowane przez badanych konsumentów pochodzenie omawianych produktów (\% wskazań)

Fig. 5. Origin of products preferred by surveyed consumers ( $\%$ of responses)

Źródło: obliczenia własne na podstawie przeprowadzonego badania ankietowego. 
Wśród ankietowanych największy udział stanowili, ci dla których zasadnicze znaczenie przy zakupie produktów regionalnych i tradycyjnych miało ich pochodzenie $\mathrm{z}$ rodzimego województwa. Na drugim miejscu znalazły się osoby preferujące krajowe artykuły regionalne i tradycyjne. Co czwarty udzielający odpowiedzi okazał się zwolennikiem lokalnych specjałów. Ta grupa uplasowała się na trzecim miejscu w strukturze wypowiedzi. Co dziesiąty badany był zainteresowany i nabywał omawiane produkty pochodzące $\mathrm{z}$ różnych krajów Unii Europejskiej. W badanej zbiorowości wystąili także konsumenci, którzy nabywali produkty regionalne i tradycyjne np. pochodzące z Ukrainy. Ich odsetek był jednak minimalny. Na podkreślenie zasługuje fakt, iż wśród badanych połowa uważała, że polskie produkty regionalne i tradycyjne są jakościowo lepsze od tego rodzaju artykułów zagranicznych. Jedna trzecia konsumentów natomiast była zadnia, że pod względem jakości te kategorie produktów są bez różnicy. Opinii na ten temat nie potrafiło wyrazić $17 \%$ ankietowanych.

\section{Podsumowanie}

W województwie podkarpackim dzięki nieskażonemu środowisku naturalnemu, bogatemu dziedzictwu kulinarnemu, a zwłaszcza zaangażowaniu producentów oraz wojewódzkich i lokalnych władz samorządowych, występuje dynamiczny rozwój rynku produktów regionalnych i lokalnych. Dostępność tych produktów jest zadawalająca dla konsumentów, bowiem mają możliwość zakupu w różnych miejscach sprzedaży, z których zainteresowani nabywcy mogą korzystać. Konsumenci z Podkarpacia zaopatrywali się w artykuły spożywcze zaliczane do wszystkich kategorii tych specjałów, a największym popytem cieszyły się produkty mięsne i mleczne oraz wyroby piekarnicze i cukiernicze. Częściej w produkty regionalne i lokalne zaopatrywały się kobiety, osoby 25-59 roku życia, mieszkańcy miast i konsumenci dysponujący dochodami powyżej 1001 zł na członka rodziny. Wraz z rosnącym znaczeniem takich atrybutów żywności jak wysoka jakość, walory sensoryczne i bezpieczeństwo odżywiania się, rola ceny jako ekonomicznego czynnika maleje. Łącznie dla $55 \%$ badanych pochodzenie produktów z własnego województwa oraz powiatu i gminy miało zasadnicze znaczenie, co świadczy o ich etnocentrycznych zachowaniach na rynku. Postawy konsumentów z woj. podkarpackiego na rynku produktów regionalnych i tradycyjnych są bardzo podobne do zachowań ogółu Polaków jak i mieszkańców państw europejskich. Potwierdzają to badania Almi, Verbeke, Vanhonacker, Nćs i Hersleth (2011). Wynika z nich, że Polacy najwyżej sobie cenią takie atrybuty tych produktów jak wysoką jakość i lokalne pochodzenie. Belgowie zwracaja uwagę zwłaszcza na smak i wysoką jakość, identycznie jak Norwedzy. Te cechy preferują na pierwszym miejscu także Hiszpanie i Włosi. Francuzi natomiast oprócz jakości, w odróżnieniu od wymienionych narodowości, mocno akcentują wysoką cenę.

\section{Literatura}

Almi, V., Verbeke, W., Vanhonacker, F., Nćs, T., Hersleth, M. (2011). General image and attribute perceptions of traditional food in six European countries. Food Quality and Preference, 22(1), 129-138.

Borowska, A. (2015). Rozpoznawalność polskiej żywności regionalnej i tradycyjnej. Biuletyn Informacyjny Agencji Rynku Rolnego, nr 1, 21-25. 
Czubała, A. (2012). Rola marketingu w realizacji społecznej odpowiedzialności przedsiębiorstw. Handel Wewnętrzny, wrzesień-październik, t. 1, 26-33.

Grzybek, M. (2009). Preferencje konsumentów z Podkarpacia dotyczące popytu na produkty regionalne. Journal of Agribusiness and Rural Development, nr 1(11), 103-110.

Grzybowska-Brzezińska, M. (2012). Uwarunkowania rozwoju ekokonsumpcji w zachowaniach konsumentów Północno- Wschodniej Polski. Handel Wewnętrzny, wrzesień-październik, t. 2, 209-217.

Jasiński, J., Rzytki M. (2007). Rynek produktów regionalnych i tradycyjnych. Biuletyn Informacyjny Agencji Rynku Rolnego, $\mathrm{nr}$ 1, 33-44.

Jąder, K. (2006). Uwarunkowania konkurencyjności produktów regionalnych w ofercie artykułów spożywczych. Prace Naukowe AR we Wroclawiu, Wrocław, nr 1118.

Jeznach, M. (2012). Jakość produktu spożywczego wśród kryteriów wyboru stosowanych przez współczesnego konsumenta. Handel Wewnętrzny, wrzesień-październik t. 2, 258-267.

Jordana, J. (2000). Traditional foods: challenges facing the European food industry. Canadian Institute of Food

Science and Technology, 33(3-4), 147-152.

Kondraciuk, P. (2015). Czy administracja publiczna powinna wspierać promocję produktów regionalnych i tradycyjnych? Biuletyn Informacyjny Agencji Rynku Rolnego, $\mathrm{nr}$ 5, 18-20.

Kowalska, A., Olszańska, A., Urban, S. (2016). Marketing produktów spożywczych i gastronomii. Wyd. Uniwersytetu Ekonomicznego we Wrocławiu, Wrocław.

Kowrygo, B., Górska-Warsewicz, M., Ługowska, K. (1997). Ocena preferencji konsumenckich w zakresie żywności i żywienia. Żywność. Technologia. Jakość, nr 2, 51-59.

Kuśmierczyk, K., Szepieniec-Puchalska, D. (2008). Zmiany w konsumpcji żywności w Polsce. Przemyst Spożywczy, $\mathrm{nr}$ 12, 6-13.

Radziszewska, A. (2015). Etnocentryczne postawy konsumentów w obliczu globalizacji konsumpcji. Handel Wewnętrzny $\mathrm{nr}$ 2(355), 334-346.

Stolzenbach, S., Bredie, W., Byrne, D. (2013). Consumer concepts in new product development of local foods Traditional versus no vel honeys. Food Research International 52, 144-152.

Woźniak, M. (2003). Model zrównoważonego rozwoju konsumpcji. Roczniki Naukowe SERiA, t. V, z. 3, 213-216. www. polskawliczbach.pl. Pobrano marzec 2017.

www.minrol.gov.pl/Jakosc-zywnosci/Produkty-regionalne-i-tradycyjne/Lista-produktow-tradycyjnych. Pobrano marzec 2017.

www.podkarpackiesmaki.pl/pl/kulinaria-podkarpackie/aktualnosci/art816,szlak-kulinarny-podkarpackiesmaki.html. Pobrano marzec 2017.

www.podkarpackiesmaki.pl/pl/kulinaria-podkarpackie/produkty/podkarpackie-produkty-zarejestro/. Pobrano marzec 2017.

www.produktyregionalne.pl/edc_media/List/Item-33/TinyFiles/Tabela-jt-wwwstyczen2017.pdf. Pobrano marzec 2017.

www.produktyregionalne.pl/produkty.html. Pobrano marzec 2017.

Żakowska-Biemans, S. (2012). Żywność tradycyjna z perspektywy konsumentów. Żywność. Nauka. Technologia. Jakość, nr 3(82), 5-18. 